\title{
CORRIGENDUM
}

\section{Bone morphogenetic proteins induce apoptosis in multiple myeloma cells by Smad-dependent repression of MYC}

T Holien, TK Våtsveen, H Hella, C Rampa, G Brede, LAG Grøseth, M Rekvig, M Børset, T Standal, A Waage and A Sundan

Leukemia (2012) 26, 1154; doi:10.1038/leu.2012.64

Correction to: Leukemia (2012) 26, 1073-1080; doi:10.1038/ leu.2011.263; published online 23 September 2011

Since the publication of this paper, the authors have noticed that Supplementary Figure S3 is incorrect, in that the pictures in S3B and $\mathrm{S} 3 \mathrm{C}$ are the same.

\author{
The Supplementary Figure has been rectified, and the \\ correct figure accompanies the online version of this \\ corrigendum.
}

The authors apologise for any inconvenience caused. 